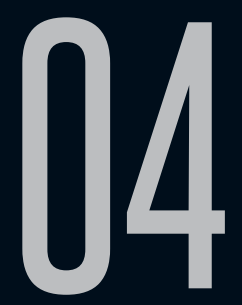

\title{
JACQUES CHESSEX: O ESCRITOR-VAMPIRO DE ROPRAZ
}

Ana Amelia Gonçalves da Costa (UERJ)

Recebido em 15 mar 2019. Ana Amélia Gonçalves da Costa é Doutora em Literatura Aprovado em 22 mai 2019.

Comparada (UERJ) e bolsista do programa Pós-Doutorado Nota Dez, da FAPERJ. Especializada em Língua e Cultura Francesas pela Universidade de Lausanne, faz pesquisa sobre a Literatura Suiça de Língua Francesa, com foco na obra do escritor helvético Jacques Chessex. Formada em Filosofia, participa do projeto de extensão universitária Órgana, do IFCS/UFRJ, de línguas instrumentais para a Filosofia, como docente de Francês. Link Lattes: http:// lattes.cnpq.br/4737061470720275

Resumo: Em Le vampire de Ropraz (2007), livro do escritor suíço de língua francesa Jacques Chessex (1934-2009), a condição da falência da memória enquanto lugar da expiação histórica é construída através da imortalidade do vampiro, que expressa, por outro lado, uma crise perene do fazer literário, crise essa que deve ser compreendida no sentido positivo de renovação. Para seguir esse caminho é preciso pensar o pós-modernismo, em consonância com a canadense Linda Hutcheon, como um movimento que questiona sistemas centralizados, hierarquizados e fechados, sem, no entanto, destruí-los. O questionamento, em Jacques Chessex, é sinônimo de ironia, traço marcante em muitos de seus escritos. No caso de Le vampire de Ropraz é parodiando o estilo romântico que Jacques Chessex tece sua crítica à hipocrisia e ao não-dito, revelando 
a ambiguidade de uma época que une degradação e progresso, conforme define Milan Kundera em seu $A$ arte do romance. $\mathrm{O}$ vampiro da obra chessexiana não tem $o$ arquétipo do personagem folclórico, distanciando o romance de uma obra de literatura fantástica. É a simbologia da exclusão, entretanto, que transfigura o protagonista no perfeito vampiro, no jogo simbólico de uma ambiguidade traduzida, pelo autor, em ruptura e transcendência identitárias.

Palavras-chave: Jacques Chessex; Literatura Suiça; Identidade autoral; Memória; Ironia.

Résumé: Dans Le vampire de Ropraz (2007), roman de l'écrivain suisse francophone Jacques Chessex (19342009), la condition de la faillite de la mémoire en tant que lieu d'expiation historique se construit à travers l'immortalité du vampire, qui exprime, en revanche, une crise perpétuelle de la production littéraire, prise dans son sens positif du renouveau. Pour suivre cette voie, il faut penser au postmodernisme avec la canadienne Linda Hutcheon, comme un mouvement qui questionne les systèmes centralisés, hiérarchisés et fermés, sans toutefois les détruire. La mise en question, chez Jacques Chessex, est synonyme d'ironie, caractéristique frappante dans plusieurs de ses écrits. En ce qui concerne Le vampire de Ropraz, à travers la parodie au style romantique Jacques Chessex élabore sa critique de l'hypocrisie et du non-dit, révélant l'ambiguïté d'une époque qui associe dégradation et progrès, selon la compréhension de Milan Kundera dans son œuvre L'Art du roman. Le vampire de l'œuvre chessexienne n'a pas l'archétype du personnage traditionnel, ce qui le distingue de la littérature fantastique. C'est cependant la symbologie de l'exclusion qui transfigure le protagoniste dans le vampire parfait, sous le jeu d'une ambiguïté symbolique traduite, par l'auteur, en rupture et transcendance identitaires.

Mots-clés: Jacques Chessex; Littérature suisse; Identité de l'auteur; Mémoire; Ironie. 
Jacques Chessex foi o único escritor suíço a receber o Prêmio Goncourt, em 1973, com o romance L'Ogre. Apesar disso, a obra do escritor suíço de língua francesa ainda é inédita no Brasil. Em vida, ele publicou mais de 30 livros de poesia; 40 romances, livros de contos e de crônicas; 10 obras reunindo ensaios e críticas literárias, e outras tantas, sozinho ou em coautoria, contendo críticas de arte. Entre seus romances, destaca-se Le Vampire de Ropraz, de 2007. ${ }^{1}$

A estrutura do romance, a exemplo de muitos outros do autor, é concisa, lancinante e vertiginosa. A narrativa factual de Le Vampire de Ropraz é fortemente ancorada no tempo e no espaço. A primeira frase do romance, reiterando o título, situa o leitor em Ropraz, cidade do Alto Jura, no cantão de Vaud. O livro começa com a morte da jovem Rosa Gilliéron, em 17 de fevereiro de 1903, e termina com o reconhecimento laboratorial do corpo de CharlesAugustin Favez, em 1920.

Seguindo sucessão cronológica, o túmulo de Rosa é violado em 21 de fevereiro. Um segundo episódio semelhante ocorre em 14 de abril, no vilarejo de Carrouge, a oito quilômetros de Ropraz. A exemplo de outras obras de Jacques Chessex, o horror não encontra limites estilísticos: um professor, vigiando a recreação de seus alunos, descobre que a "bola" do jogo de futebol é o crânio de Nadine Jordan. "Na hora seguinte, todo o horror do ritual fúnebre é descoberto. Túmulo aberto, caixão sem lacre, ali também, cadáver violado, manchas de esperma e de saliva ao redor do umbigo e nas $\operatorname{coxas}^{\prime 2}$ (CHESSEX, 2007, p.37-38). O túmulo da terceira vítima, 1 A tradução do romance "Le Vampire de Ropraz" é parte de meu projeto de pósdoutorado, contemplado com a bolsa Pós-Doutorado Nota Dez, da Faperj.

2 Todas as traduções do romance aqui citadas foram feitas por mim. 
Justine Beaupierre, é violado no mesmo mês de abril. O tipo físico das três jovens é o mesmo, fazendo supor que o necrófilo escolhe antecipadamente as suas vítimas.

O vilarejo de Ropraz é pintado como um local "de lobos e de abandono no começo do século XX" (CHESSEX, 2007, p.11). O campo lexical da descrição inclui os adjetivos "pendurado", "opacos", "desertos", "sombrios", "estreitos" e "baixas". Na zona rural, Ropraz é uma cidade marcada por altos índices de enforcamento dentro das fazendas: "As ideias não circulam, a tradição pesa, a higiene moderna é desconhecida. Avareza, crueldade, superstição, não estamos longe da fronteira de Friburgo, onde a bruxaria aflui" (2007, p.11). A lei é a do medo. Medo do sobrenatural, dos lobos e dos ursos. Por isso, as armas sempre estão carregadas, as armadilhas montadas. À noite, preces de conjuração ou de exorcismo enchem o ar, apesar do protestantismo reinante.

$\mathrm{Na}$ cidade agrícola e pobre, a ameaça vem de fora e o estrangeiro é o indiscreto e o ladrão. Sem uma vida digna desse nome, a população local acaba se assemelhando aos porcos, tamanha a convivência com os suínos. A miséria, entretanto, não se resume a questões econômicas, já que "a miséria sexual, como será designada mais tarde, se une à errância do medo e da imaginação do mal" (CHESSEX, 2007, p.13). A culpabilidade por esses exacerbados instintos sexuais vem, obviamente, dos "quatro séculos de calvinismo imposto". Paralelamente, o inverno, com sua melancolia, atiça os nervos. Assim, os rituais, as preces e as poções negras da descrição chessexiana sobrepujam e escondem qualquer possível rastro de beleza do lugar. Com essa ambientação macabra, o autor constrói um clima de chegada da ameaça, naquele que é o espaço de vitória da loucura e do medo. 
Estamos na metade do romance. Onze de maio de 1903. É nesse ponto que o autor nos apresenta Charles-Augustin Favez, de 21 anos, jovem que tem o costume de praticar sexo com os animais da fazenda: "E ele se diverte com nossos animais! Ele rondaria nos cemitérios? E se o culpado fosse Favez, Favez no túmulo de Rosa, ainda ele em Carrouge, ainda Favez em Ferlens! Claro que é Favez, o sádico. É Favez, o monstro. É ele, o vampiro de Ropraz" (CHESSEX, 2007, p.47).

Assim que entra em cena, o passado do jovem desajustado é revelado: nascido em um meio desfavorecido, em que predominam o incesto e o alcoolismo, aos três anos de idade Favez é retirado da família. Começa, então, uma sequência de abusos e explorações nas famílias em que é alocado. Por sua vez, o menino cresce com episódios de ausência e perda de memória, além de crises de cólera e tendência ao alcoolismo. É o bode expiatório perfeito para os crimes que precisam de um culpado, em uma sociedade que "precisa limpar o país do monstro que envenena a sua existência" (2007, p.69).

Encarcerado, Charles-Augustin Favez começa a receber a visita de uma misteriosa dama que se veste de branco. É nesse ponto que o autor inicia seu jogo de reversões que, analisado no decorrer do presente artigo, revela tanto a paródia ao estilo romântico operada pelo autor quanto a crítica à hipocrisia e ao não-dito, recorrentes na sociedade helvética lida por Jacques Chessex. Em sua cela, o denominado vampiro tem medo da mulher sem identidade que o assedia e tem medo na população vingativa que clama por sangue. O medo é tanto que ele tenta se matar. E nem isso ele consegue.

Apesar de algumas evidências contrárias, em 24 de dezembro de 1903, ironicamente data da véspera de Natal, Charles-Augustin 
Favez, o vampiro de Ropraz, é condenado à prisão perpétua. Após 12 anos aprisionado no hospital psiquiátrico de Cery, Favez consegue fugir e se alistar como voluntário no exército francês. Na Legião Estrangeira, seu comandante é Frédéric Saucer, "que escreveu alguns poemas sob o nome de Blaise Cendrars" (2007, p.85). A proximidade dos dois faz com que Cendrars arranque algumas confidências de seu comandado, que servirão de base para a futura escritura do livro que será intitulado Moravagine. De personagem-vampiro a personagem-inspiração, a saga de CharlesAugustin Favez não poderia ter fim com a sua morte. Não tem.

Morto no mesmo combate em que Blaise Cendrars tem o braço direito arrancado, o corpo do vampiro de Ropraz fica abandonado em campo de batalha e seu rastro se perde. Até o dia do sorteio do soldado desconhecido, em 21 de novembro de 1920. "É sobre os restos de um único herói anônimo que arderá a chama que jamais se apaga, sob o glorioso Arco do Triunfo" (2007, p.86). Pesquisas de DNA permitiram supor que os restos do soldado desconhecido pertenceriam ao cidadão vaudois Charles-Augustin Favez, alistado voluntariamente, em fevereiro de 1915, no exército francês em guerra. O soldado teria sido morto em frente à Fazenda Navarin no dia 28 de setembro do mesmo ano.

O soldado desconhecido, heroicamente honrado pelo Chefe de Estado, pelas badaladas aos mortos e pela saudação à Bandeira a cada 14 de julho, ninguém mais seria do que um louco e um criminoso reincidente de origem suíça, da mais terrível memória no alucinado repertório de relatos dos mortos-vivos. É óbvio que as autoridades em questão fizeram vista grossa sobre os resultados dessa análise e o escândalo foi abafado. Dessa forma, diz Chessez 
em seu romance, somos poucos a desconfiar: no glorioso Arco do Triunfo, sob a chama do soldado desconhecido, repousa Favez, o vampiro de Ropraz, que dorme com um olho só, enquanto espera uma nova noite para despertar.

Como veremos a seguir, toda a trama elaborada por Jacques Chessex se presta a leituras diversas, entre as quais a experiência do tempo circular na ficção, enquanto artifício da memória vista como recusa do esquecimento. Sob o manto da ironia, a memória desvelada pelo escritor faz emergir um tempo-verdade ambíguo e paradoxal, ancorado em um espaço que inclui tudo aquilo que não aparece. A paródia do estilo romântico se presta, assim, como opção literária para efetuar ficcionalmente uma reelaboração crítica do passado. Nos meandros desses jogos, nada mais oportuno do que transformar o imortal e sanguinário vampiro em personagem eternamente reverenciado, ironicamente aprisionado no túmulo do herói desconhecido.

\section{ETERNIDADE E CIRCULARIDADE}

O vampiro é, antes de tudo, a figura mítica da eternidade. Na obra de Chessex, a designação ocorre no capítulo IV. O vampiro de Ropraz, como a imprensa alcunhou o violador da tumba de Rosa, é o "bebedor de sangue". Muitos são os candidatos a "vampiro" e o medo está na ordem do dia. Em Le Vampire de Ropraz o rumor é o vento que espalha o ódio e a violência: "Inveja, ciúme mesquinho, acerto de contas ancestrais, pretendentes rejeitados por Rosa ou por seu austero pai, particulares lesados por decisões do juiz, politiqueiros focados em suas carreiras, solitários, tímidos, compulsivos apaixonados e obcecados pela pureza da bela 
jovem..." (CHESSEX, 2007, p.25). O medo é tanto que "[...] por todos os lados apareceram as imagens do Cristo guardadas do tempo do Catolicismo" (2007, p.26).

É preciso assinalar, para compreender a força da alcunha, que Ropraz fica a menos de 50 quilômetros de Friburgo, onde, até a metade do século XVIII, a Justiça condenava cidadãos acusados de praticar bruxaria. Friburgo detém o nefasto recorde de ser o cantão suíço que mais queimou "bruxos" entre os séculos XV e XVIII. ${ }^{3}$

Paralelamente, a relação do vampirismo com o movimento romântico é tão histórica quanto metafórica. Visando revolucionar uma arte subsumida ao reino do classicismo e da razão, os românticos das letras francesas sofrem com a expressão de suas finitudes, tédio e melancolia. O século em questão é o XIX, que em sua linhagem romanesca testemunha o entusiasmo pelo romance noir, fantástico e irracional. La Peau de chagrin, de Balzac, foi publicado em 1831; "La Morte amoureuse", de Gautier, é um conto de 1836. Entre 1856 e 1875, Paul Féval publica Les Drames de la mort, Le Chevalier Ténèbre e La Villa-vampire, romances que têm por tema o vampiro.

Em um artigo intitulado "Le vampirisme, de la légende à la métaphore ${ }^{\prime \prime}$, Jean Marigny, professor da Universidade Stendhal, em Grenoble, e especialista do mito do vampiro, afirma que a palavra vampiro aparece na língua francesa no início do século XVIII, tendo

3 In http://www.rts.ch/video/info/couleurs-locales/5748655-fribourg-est-I-un-descantons-romands-a-avoir-le-plus-brule-de-sorciers-entre-le-15e-et-le-18e-siecle.html Acesso em 22.Jan.2019.

4 Artigo apresentado no colóquio sobre o vampirismo na literatura e nas artes, ocorrido em Cerisy-la-Salle, em agosto de 1992. Publicado na obra: FAIVRE, Antoine (1993) (org.). Les Vampires - Colloque de Cerisy. Cahiers de l'Hermétisme. Paris: Éditions Albin Michel. 
o conceito de vampirismo evoluído na literatura, no cinema e nas artes gráficas a partir do século XIX. Ao abordar o alargamento do campo semântico da palavra "vampiro", Jean Marigny enfatiza os desvios de sentido em que o sangue passa a ter valor simbólico:

Victor Hugo utilizou o termo "vampiros" para designar os tiranos de toda espécie e, no século $X X$, os bolcheviques, avatares de "o homem com a faca entre os dentes", depois os nazistas e os stalinistas que reinaram pelo terror, sem esquecer os capitalistas sedentos de riquezas, foram constantemente comparados a vampiros. Seja qual for a cor política à qual pertençamos, somos naturalmente tentados a considerar os representantes de campos opostos como vampiros. (1993, p.18 - tradução minha)

Ao completar sua análise, Jean Marigny cita a aparição metafórica do termo no meio médico, quando o termo vampiro foi aplicado a certos tipos de doentes mentais, mencionando casos de necrofilia, violência e sadismo. E conclui:

Esse tipo de desvio semântico nos conduz a léguas de distância dos vampiros tradicionais dos Cárpatos, mas nos mostra, evidentemente, que, há mais de dois séculos, o vampirismo, que era apenas o produto de superstições de outra era, foi revestido de valores metafóricos que refletem preocupações do mundo moderno. Essa evolução é particularmente sensível na literatura e nas artes. (1993, p.21 - tradução minha)

O jovem alcoólatra e desajustado Charles-Augustin Favez tem o perfil perfeito para dar corpo ao vampiro de Ropraz, agravado pelo fato de ter sido colega de turma da vítima Rosa Gilliéron. Assim, Favez faz parte da memória de Rosa. Ao amarrar os fios das memórias de 
seus personagens, Jacques Chessex constrói uma experiência do tempo que substitui a noção de eternidade por aquela, ricoeuriana, de circularidade. Esse caráter circular da proposição ricoeuriana repousa na assertiva de que "o que se narra é o tempo, a ação que se desenvolve no tempo e que é refigurada pela narração", conforme resume Constança Marcondes Cesar no artigo "Temporalidade e literatura". ${ }^{5}$ Ela completa: "Condensando o tempo, a narração apresenta a vida como uma totalidade, fazendo aparecer sua relação com a experiência vivida do leitor e pondo em relevo a relação entre o quantitativo e o qualitativo do tempo" (2011, p.170).

No artigo supracitado, Constança Marcondes Cesar compreende, a partir da obra em três volumes Tempo e narrativa, de Paul Ricoeur, que:

O homem não apenas está no tempo, na sucessão cronológica dos dias e das horas, mas é tempo, isto é, existe num horizonte que, pela memória, abarca o passado e, pela prospecção, pelo projeto, indaga e delineia o futuro. Desdobrando-se em passado, presente e futuro, tornando o passado presente a si pela memória, e o futuro também presente pela antecipação e projeto do agir e do ser, o homem presente a si, consciente de si, se expressa no tempo e como tempo. Assim, a consciência é, para o homem, consciência de si, desvendada ao longo da vida, no tempo. (2011, p.165)

Esse tempo em cujo horizonte reside a memória, passado no presente, é aquele que, na interpretação de Paul Ricoeur, é re(a) presentado pela ficção. Se a memória é a reunião de dois tempos,

5 Artigo pulicado em: PAULA, Adna Candido de (2011); SPERBER, Suzi Frankl (Org.). Teoria literária e hermenêutica ricoeuriana - Um diálogo possível. Dourados, MS: UFGD, p.165-175. 
a noção vampiresca de eternidade pode ser interpretada como circularidade e permanência, posicionando o romance de Jacques Chessex no presente espaciotemporal, substantivo e verbo, de um homem que se expressa no tempo e como tempo. Esse tempo é também aquele metaliterariamente indicado na paródia que, em suas duas vozes, trabalha com a presença (gênero pós-moderno, parodístico) e com a ausência (texto romântico, parodiado).

O tempo (circular) da narrativa chessexiana é aquele da recusa do esquecimento. Só assim, atualizando a memória abraçada ao esquecimento, é que o narrador Jacques Chessex dialoga com seu leitor. A experiência compartilhada por Chessex é a (sua) experiência individual, que, ao ocupar o lugar da experiência coletiva relacionada à tradição oral, é aquela proporcionada pelo romance, conforme teoriza Walter Benjamin, especialmente em seu "O narrador".

Paralelamente, o vampiro de Ropraz enterrará suas memórias em um túmulo eterno. Para que o horror da guerra jamais seja esquecido, é erigido o túmulo do herói desconhecido. Em uma circularidade temporal exemplar, nada mais irônico do que a qualificação de vampiro para esse herói de guerra anônimo. Assim, a memória eterna não terá como oponente o esquecimento, e sim, o anonimato. Esquecer não é o mesmo que desconhecer, parece nos revelar Chessex. O vampiro de Ropraz não poderá ser relegado ao esquecimento porque, anônimo, tornou-se eterno.

É também assim, no anonimato que gera a eternidade, que a crítica de Jacques Chessex se expande ao tempo cristão da unicidade e da proximidade do fim. A humanidade está condenada ao recomeço em fluxo ininterrupto, parece nos dizer Chessex, e precisa aprender a conviver como essa tortura. O mito do vampiro, conforme nos indica 
Claude Lecouteux no livro História dos vampiros: autópsia de um mito (2005), é construído no terreno da incerteza:

Mas o que nos diz o mito? Se nos ativermos à definição etimológica do termo, trata-se de uma linguagem, portanto o vetor de uma mensagem de valor universal, resultado de uma visão do mundo, explicação de questionamentos suscitados pela experiência. Diz-nos que aquilo que o cristianismo, religião dominante, afirma sobre a vida e a morte é inexato, que não há fronteira nitidamente perceptivel entre estas, que o morto possui também uma existência, que ele pode falar e agir, desde que the forneçam um motivo. (2005, p.176)

A essa definição do significado mítico do vampiro, ser configurado no limiar entre os tempos da vida e da morte, podemos unir a concepção cristã de finitude. A alma imortal cristã alcança a sabedoria e, portanto, não pode ser aquela sujeita ao eterno retorno. O tempo cristão é finito e irreversível. Na ficção, entretanto, conforme nos ensina Paul Ricoeur, o tempo tornase tempo humano na medida em que está articulado de modo narrativo e a ação temporal é refigurada pela narração. Dessa forma, as fronteiras entre o tempo real e o tempo narrado são rompidas, para que emerja uma nova experiência temporal. A recusa ao esquecimento é, assim, metáfora do tempo que ainda virá, que sempre virá, carregando em seu manto os rastros daquilo que foi e, presentâneo, os rastros daquilo que é.

\section{A MEMÓRIA DO TEMPO E O TEMPO DA MEMÓRIA}

Analisada pelo prisma de desvelamento da memória, que caracteriza a obra do autor, a questão do tempo em Jacques Chessex 
parece coincidir com a visão aludida por Milan Kundera no início de seu $A$ arte do romance. Na obra teórica A arte do romance (2009), publicada em 1986, o escritor tcheco Milan Kundera considera que o romance "sonda o tempo", de forma que "o caminho do romance se esboça como uma história paralela dos tempos modernos" (2009, p.16). Entre os denominados paradoxos terminais dos tempos modernos, relacionados por Kundera à evolução do gênero romanesco, está aquele que parece nortear as obras tardias de Jacques Chessex:

Por exemplo: os tempos modernos cultivavam o sonho de uma humanidade que, dividida em diferentes civilizações separadas, encontraria um dia a unidade e, com ela, a paz eterna. Hoje, a história do planeta forma, enfim, um todo indivisível, mas a guerra, ambulante e perpétua, é que realiza e assegura essa unidade da humanidade há muito tempo sonhada. A unidade da humanidade significa: ninguém pode escapar em nenhum lugar. (2009, p.18)

Ninguém pode escapar em nenhum lugar. Entre os quatro apelos do romance (apelo da diversão, apelo do sonho, apelo do pensamento e apelo do tempo), Milan Kundera define o apelo do tempo como:

O período dos paradoxos terminais incita o romancista a não limitar mais a questão do tempo ao problema proustiano da memória pessoal, mas estendê-la ao enigma do tempo coletivo, do tempo da Europa, a Europa que se volta para olhar seu passado, para fazer seu balanço, para apreender sua história, como um velho que apreende com um único olhar sua própria vida escoada. $(2009$, p.20) 
A expressão "paradoxos terminais da modernidade" é utilizada por Kundera para designar a ambiguidade de uma época que é "ao mesmo tempo, degradação e progresso" (2009, p.12). Ou seja, é uma expressão que anuncia a estética romanesca de um tempo histórico assolado por duas guerras mundiais e que, concomitantemente, ergue-se sobre um período estreitado entre os modos de pensar moderno e pós-moderno. Nesse momento de reconfiguração do pensar, dois pontos que unem o moderno e o pós-moderno nos interessam particularmente: as novas formas de lidar com o tempo e com o passado, e as relações entre ficção e realidade.

Defendendo que "o romance acompanha o homem constante e fielmente desde o princípio dos tempos modernos" (2009, p.13), Milan Kundera usa a imagem do Dom Quixote que saiu de casa "e não teve mais condições de reconhecer o mundo" (2009, p.1314) para espelhar uma era, a moderna, em que vigora a sabedoria da incerteza, ou seja, "ao invés de uma só verdade absoluta, muitas verdades relativas [que] se contradizem" (2009, p.14). É nessa sabedoria da incerteza - a relatividade essencial das coisas humanas - que Jacques Chessex edifica sua obra tardia e constrói personagens como Charles-Augustin Favez, de Le Vampire de Ropraz. A sabedoria da incerteza reveste a dupla função de iluminar novos modos de pensar complementares, que situam a pós-modernidade como um processo mais reflexivo do que recusador, ao mesmo tempo em que posiciona Jacques Chessex no lugar concedido ao intelectual por Umberto Eco, como aquele que incomoda, por ser a consciência crítica do grupo. ${ }^{6}$

6 ECO, Umberto (2003). "A função dos intelectuais". Revista Época, fev.03. Inhttp:// revistaepoca.globo.com/Revista/Epoca/0,,EDR55351-6075,00.html. Acesso em 29Jan.2019. 
Jacques Chessex, em seu fazer literário, posiciona-se, assim como Milan Kundera, como agente desafiador de tudo o que parece culturalmente óbvio e iluminado. Especialmente na forma de lidar com o tempo, fator que, na escritura de Chessex, é conjugado ao espaço. O tempo-verdade ambíguo e paradoxal, iniciado na modernidade e estendido ao pós-moderno, é revelado, na obra de Jacques Chessex, através da ironia. É nesse espaço paradoxal, portanto, que o autor propõe um diálogo entre passado e presente, em que a relação temporal é crítica e não, nostálgica.

Tal postura crítico-dialogal é por si só pós-moderna, se considerarmos com Linda Hutcheon, em Poética do pósmodernismo: história, teoria, ficção (1991), que a "poética"7 do pósmodernismo é válida enquanto "estrutura conceitual flexível que possa, ao mesmo tempo, construir e conter a cultura pós-moderna e nossos discursos tanto a seu respeito como adjacentes a ela" (1991, p.11). A teórica canadense - para quem "o pós-moderno é um fenômeno contraditório, que usa e abusa, instala e depois subverte, os próprios conceitos que desafia" (1991, p.19) - argumenta que, no seio das contradições do autorreflexivo e do histórico, "o que há de mais novo é a constante ironia associada ao contexto da versão pós-moderna dessas contradições, bem como sua presença obsessivamente repetida" (1991, p.13).

É nessa trilha, portanto, de relevo das contradições, em um tempo-espaço contextualizado ${ }^{8}$ que utilizamos o conceito de pósmoderno. É na "presença do passado", enquanto "uma reavaliação

\section{Aspas da autora.}

8 Enfatizamos aqui a ideia de Hutcheon de que o pós-modernismo "não pode ser utilizado como sinônimo para o contemporâneo", já que "não descreve um fenômeno cultural internacional, pois é bastante europeu e (norte- e sul-) americano" (1991, p.20). 
crítica, um diálogo irônico com o passado da arte e da sociedade" (HUTCHEON, 1991, p.20), que relacionamos pós-modernismo à produção literária de Jacques Chessex. Na obra do suíço, o passado não é recuperado melancolicamente, mas memoriado através de seus rastros, na experiência temporal da reelaboração crítica. Ou seja, o passado helvético, desconhecendo silêncios e encarceramentos, é recuperado por Chessex através do processo autoral que Linda Hutcheon resume como o "irônico repensar pósmoderno sobre a história".

De acordo com nossa leitura, o personagem do vampiro construído por Jacques Chessex incarna à perfeição o apagamento de fronteiras entre o histórico e o ficcional. A ideia, acompanhando Linda Hutcheon, é de que, se anteriormente a história era utilizada na crítica de romances, enquanto modelo da visão realista da representação, "a ficção pós-moderna problematiza esse modelo com o objetivo de questionar tanto a relação entre a história e a realidade quanto a relação entre a realidade e a linguagem" (1991, p.34).

Na escritura, a tradução dessa recuperação temporal, ou seja, a tradução dessa memória, é erguida através de apropriações e citações paródicas, através de referências muitas vezes deformadas. Linda Hutcheon qualifica essa tendência literária como "metaficção historiográfica", que, ao incorporar "a autoconsciência teórica sobre a história e a ficção como criações humanas", passa a ser "a base para o seu repensar e sua reelaboração das formas e dos conteúdos do passado" (1991, p.22).

A relação entre tempo vivido e narração é justamente o tema de Paul Ricoeur em seus três volumes de Tempo e narrativa. No segundo volume de Tempo e narrativa (2010), Ricoeur explicita que 
narrar é 'refletir sobre' os acontecimentos narrados, de maneira que "a ficção [...] não cessa de fazer a transição entre a experiência antes do tempo e a experiência depois dele" (2010, p.125). Ou seja, a narrativa não está afastada do vivido, a ele retornando em uma operação de mútua transformação, traduzida como nova "experiência fictícia do tempo" (2010, p.129).

Em seu poder de projetar um mundo, "cada romance diz ao leitor: 'as coisas são mais complicadas do que você pensa'" (KUNDERA, 2009, p.21). É assim que a âncora no tempo, de 1903 a 1920, e no espaço, a pacata cidade suiça de Ropraz, aprisiona o leitor do romance de Jacques Chessex a uma limitação aparentemente confortável. No coração da Europa mergulhada em sua primeira guerra mundial, até mesmo um espaço perdido no continente precisa revolver suas camadas de terra para fazer emergir um significado temporal.

Ao sussurrar que "as coisas são mais complicadas do que você pensa", Jacques Chessex, em boa parte de sua obra, reabre a ferida da memória coletiva negada, apagada, escamoteada. Em Le vampire de Ropraz, o processo de desvelamento da memória coletiva é construído através de elementos como a paródia de artifícios românticos e a ironia como viés de estabelecimento de acasos, estando o primeiro contido no segundo e vice-versa.

Assim sendo, uma leitura possível para Le Vampire de Ropraz é aquela da falência da memória enquanto lugar da expiação histórica. Homenagear o soldado desconhecido não corresponde, em Le Vampire de Ropraz, ao que tradicionalmente seria proposto, ou seja, um ato de respeito e reverência aos que morreram por nós e por nossa pátria e/ou uma advertência ao que não se deve repetir 
jamais. O vampiro-soldado "dorme de um só olho enquanto espera novas noites para correr". E, como nos provam os acontecimentos posteriores aos da Primeira Guerra Mundial, evento abordado no livro de 2007, muitas foram as ocasiões em que a vigília do personagem significou uma cruel condenação à eternidade.

Assim, a imortalidade do vampiro - personagem essencialmente literário - pode exprimir justamente uma crise perene do fazer literário, crise essa compreendida em seu sentido positivo, de renovação. O questionamento, em Jacques Chessex, é sinônimo de ironia, traço marcante em muitos de seus escritos e que ilustra, a contento, sua postura de provocador. No caso de Le vampire de Ropraz é parodiando o estilo romântico que Jacques Chessex tece sua crítica à hipocrisia, aqui tomada tanto em seu sentido artístico, de falsa aparência, quanto em seu aspecto moral, de dissimulação.

Ao recorrer a um personagem tão carregado de significados quanto o vampiro, Jacques Chessex pretende se apropriar de um mito que remonta à memória dos tempos para construir literariamente uma dupla operação relacionada à memória, na dimensão (romântica) da luz e da sombra: iluminar, com seu texto, um fait-divers macabro da ordem do não-dito e render um culto à memória através de sua negação, já que a memória da guerra passa a eternizar-se através do banido, do excluído, que ocupa o espaço do herói nacional.

\section{CONTRASTE ROMÂNTICO ENTRE LUZ E SOMBRA}

A descoberta da subjetividade é marca do espírito romântico. No lugar do homem clássico, guiado por uma razão infalível e resignado com um destino imutável, surge o complexo homem romântico, 
revoltado contra o mundo ou contra a sociedade. Uma leitura simplificada da paródia romântica operada por Jacques Chessex em Le Vampire de Ropraz poderia nos conduzir, assim, à análise do personagem Favez como um anti-herói plano, impossibilitado, portanto, de existir no interstício da imprevisibilidade, na comunhão entre herói e vilão.

Heresias, blasfêmias e conversões são temas das religiões românticas, conforme analisa Octavio Paz, em Os Filhos do Barro (1984). Charles-Augustin Favez, rapidamente enquadrado na categoria de debilitado mental, é construído justamente na fluidez identitária, na ausência de subjetividade que, longe de caracterizar o herói romântico, é um recurso extremante irônico que rima com a análise expandida de Octavio Paz:

Religiões românticas: heresias, sincretismos, apostasias, blasfêmias, conversões. A ambiguidade romântica tem dois métodos, no sentido musical da palavra: um se chama ironia e consiste em inserir dentro da ordem da objetividade a negação da subjetividade; o outro se chama angústia e consiste em deixar cair na plenitude do ser uma gota do nada. A ironia revela a dualidade daquilo que parecia uno, a cisão do idêntico, o outro lado da razão: a quebra do princípio da identidade. A angústia nos mostra que a existência está vazia, que a vida é morte, que o céu é um deserto: a quebra da religião. (1984, p.68).

Se em determinado ponto do romance de Jacques Chessex o vampiro se torna a personalização do medo parece ser porque, violado, se aproxima de todos os estereótipos do feminino romântico: impressionável, sentimental, incoerente e volúvel. A oposição que 
coaduna com uma organização binária do pensamento romântico, explicitada pelo contraste entre luz e sombra na obra chessexiana, é aqui representada pela personagem da misteriosa dama branca. No terreno da ilusão, ou da sombra, a mulher é a imagem platônica projetada na parede da caverna. Ou entre as paredes da prisão.

A dama branca é o duplo de Favez e, ao mesmo tempo, alude a personagens femininos chessexianos que encontramos em alguns de seus outros romances. ${ }^{9} \mathrm{~A}$ identidade da misteriosa dama que visita Favez na cela não será revelada, ela tanto pode ser "uma santa mulher vinda para trazer o conforto de Deus a um proscrito da sociedade" (2007, p.62), quanto uma visitadora de prisões, ou uma histérica, em busca de aventuras.

O jogo de vinculação entre os rituais sexuais e sagrados é recorrente na obra de Chessex. Não por acaso é a dama branca, símbolo do amor fúnebre, duplo do vampiro negro, que pronunciará o "sacramento do monstro", condenando Favez a ser um "vampiro para a eternidade": "Tem o sacramento do monstro, como tem, há dois mil anos, aquele do padre ao altar. Sacerdos eris in aeternum. Vampyrus eris in aeternum." (CHESSEX, 2007, p.77). Eternos serão os sacerdotes e os vampiros. No ritual invertido, é a dama branca que viola o vampiro, bebe seu sangue, profana o seu túmulo. E, assim fazendo, (re)transforma o monstro em humano.

A dama de branco, personagem introduzida por Jacques Chessex no capítulo XI de Le Vampire de Ropraz, faz o contraponto ficcional

9 Em Avant le matin, a jovem mártir é Béatrice Conte, que pratica sexo com os menos favorecidos, a exemplo de sua mentora Canisia Piller, por piedade e para praticar o dom de si mesma. Em La Mort d'un juste, é a elegante Eva Courbet que faz visitas íntimas ao teólogo Aimé Boucher, sedutor hedonista de jovens inexperientes e blasfemador enfeitiçado por seus próprios demônios, em seu refúgio de aposentadoria antecipada. 
com o vampiro, ao mesmo tempo em que estilisticamente parodia o romance gótico. Em Jacques Chessex, o cenário da aparição da dama de branco é a cela de Favez em sua cadeia medieval:

Com o que sonha um vampiro, à noite, trancado a sete chaves em sua cadeia medieval, ele relembra cenas da infância: morrer de fome, sofrer, suportar, se submeter, constantemente querer morrer. Fechado na cela das enegrecidas prisões de Oron, Favez redescobre antigas cenas que ele acreditava poder afastar de sua memória de errante livre. $(2007$, p.57)

Mesmo no texto de sua ficção, em Chessex a memória comunga com o esquecimento, assim como, em uma linha divisória fluida e ambígua entre os dois personagens - Favez e a dama de branco -, o vampiro, não-morto, simbolizaria a memória eterna, a impossibilidade do esquecimento. Na antinomia luz/sombra, o vampiro está ao lado dos símbolos negativos, da escuridão noturna com suas forças maléficas e insegurança moral. Conforme registra Claude Herzfeld, no artigo "Les racines anthropologiques de l'imaginaire dans le Dracula de Bram Stoker"10.

O Drácula de Stoker apresenta uma estrutura antitética que caracteriza o registro diurno do imaginário. As trevas e as imagens de angústia se opõem às imagens de luz, de ascensão e de conquista. Enquanto a noite tem uma existência simbólica autônoma, a luz está ali para valorizar negativamente as trevas. (1993, p.133 - tradução minha)

A luz, nesse trecho do romance de Chessex, em que surge a mulher misteriosa, seria então, aparentemente, essa dama, não de Bram Stoker". In: FAIVRE, Antoine (1993) (org.). Les Vampires - Colloque de Cerisy. Cahiers de I'Hermétisme. Paris: Éditions Albin Michel, p.133-145. 
por acaso de branco. Já na apresentação da personagem, o jogo de luz e sombra parodiado fica explícito. A dama veste-se de branco, misteriosa e muda. O cocheiro porta um uniforme escuro. A crepuscular hora da visita, dezoito horas, é justamente aquela em que o vampiro inicia suas atividades.

A aparente oposição entre o sombrio Favez e a luminosa dama de branco é, entretanto, revertida por Jacques Chessex, em uma deformação que também revela a contestação paródica. Mais do que oposição, podemos falar de forças em conflito, de forma que, em nossa leitura, a mulher de branco pode representar justamente o lado negro que falta a um vampiro débil, através do poder que ostenta. Ela recebe a chave da cela de Favez do vigia carcereiro, certamente pagando por isso. As visitas da misteriosa mulher se repetem, sem que ela tenha receio de penetrar sorrateiramente em um edifício oficial e de seduzir um condenado à reclusão perpétua. Favez tem medo da visitante.

A introdução da dama de branco no enredo parece ser uma piscadela de olho de Jacques Chessex ao próprio gênero gótico, cujo medo é tantas vezes originado justamente a partir do contraste entre luz e sombra. A mulher de branco é, então, aquela que vai violar o vampiro, buscando voluntariamente o estatuto do sombrio, da escuridão. Dessa vez, não é o vampiro que sugará o sangue de sua vítima, mas o contrário: é a vítima que vai esvaziar as veias do algoz e, consequentemente, contaminá-lo. Assim, o vampiro, símbolo do apetite de viver, transfere ao outro essa fome voraz e autodestrutiva. Atormentado por sua finitude, o devorado engendra o devorador, para, em seguida, ser por ele destruído. 


\section{O ESCRITOR-VAMPIRO}

Como já vimos anteriormente, o vampiro do livro Le Vampire de Ropraz não tem o arquétipo do vampiro folclórico, distanciando o romance de uma obra de literatura fantástica. É a simbologia da exclusão, entretanto, que transfigura Charles-Augustin Favez no perfeito vampiro, tese reforçada pela frase que encerra o romance, na qual Chessex retoma a alcunha e faz com que seu protagonista, agora "dormindo" ("de um só olho") em túmulo sagrado, espere por "novas noites para correr".

A exclusão do vampiro é representada visceralmente na indecidibilidade vida-morte, mas alargada para outras dicotomias - luz/escuridão; homem/animal; finitude/eternidade -, que traduzem, conforme analisa Claude Lecouteux em sua História dos vampiros: autópsia de um mito (2005), "a inquietação que nasce de uma ruptura da ordem, de uma fissura, de um deslocamento, de uma contradição" (2005, p.15). Esses "rasgos" estão obviamente relacionados a uma questão ancestral que preocupa os homens, a curiosidade sobre o que há e o que acontece após a morte, esgarçada a ponto de criar um ser capaz de transitar entre dois mundos, não sendo nem vivo nem morto.

É também na ordem da ruptura e da transcendência que, de uma maneira geral, Jacques Chessex prefere enquadrar a sua obra. A partir dessa ideia, podemos comparar o autor ao próprio personagem. Ao gosto de Flaubert, escritor de sua predileção e sobre o qual publicou, em 1991, o ensaio Flaubert ou le désert en abîme, Jacques Chessex escreve em Le Vampire de Ropraz: "[...] vampiro de Ropraz, meu duplo, meu irmão!" (2007, p.78). Duplo na exclusão e fraterno no abjeto, este último conceituado por Julia 
Kristeva, em seu Pouvoirs de l'horreur: essai sur l'abjection ${ }^{11}$ (1980), como "aquilo que perturba a identidade, o sistema, a ordem. Aquilo que não respeita as fronteiras, as posições e as regras. 0 entre-dois, o ambíguo, o composto." (1980, p.12, tradução minha).

Assim como um vampiro, Chessex sabe que incomoda, mas também sabe o que representa. Em reportagem ao jornal suíço "Le Messager", em 15 de junho de 2007, na ocasião de lançamento do romance Le Vampire de Ropraz, a foto que ilustra a matéria tem como cenário o cemitério de Ropraz, com a legenda: "O escritor Jacques Chessex, 73 anos, mora em Ropraz há cerca de trinta anos, em frente ao cemitério que o fascina" ${ }^{12} \mathrm{O}$ cemitério, o mesmo em que está enterrada Rosa Gilliéron, era um local constantemente visitado pelo escritor, que na mesma reportagem declara: "Esse livro, eu poderia tê-lo escrito há quarenta anos. Quando comecei a perambular em Ropraz, antes mesmo de morar na cidade, já ouvi a história do vampiro". Curiosamente, é hoje o mesmo cemitério em que está enterrado o corpo de Jacques Chessex, falecido em 2009.

Transformar o fait divers, o rumor, em romance alinhava algumas obras de Jacques Chessex, livros em que os arquivos da memória helvética parecem ter sido remexidos, apropriados e regurgitados como instrumentos de recusa à vontade de esquecimento. São obras que reformulam a memória, a relação do homem com o passado, designada por Paul Ricoeur, em A memória, a história, o esquecimento (2007), como uma relação em que "[...] boa parte da busca do passado se encaixa na tarefa de não esquecer" $(2007$, p.48).

11 KRISTEVA, Julia (1980). Pouvoirs de l'horreur: essai sur l'abjection. Paris: Éditions du Seuil.

12 In http://lemessager.ch/Archives/messager07/Juin\%2007/MESS\%2015-06-07/ME15-06-01.pdf Acesso em 22.Jan.2019. 
É no sentido dessa busca-tarefa que, em Chessex, o espaço assume real importância, alinhando o escritor, no território construído a partir da polaridade reclusão-abertura, ao vampiroexcluído, ao vampiro-testemunha e ao vampiro-ruptura, todos eles relacionados ao esquecimento. Ao discorrer sobre "reflexividade" e "mundanidade", sintagmas integrantes do tema da memória e da reminiscência, Paul Ricoeur admite:

Não nos lembramos somente de nós, vendo, experimentando, aprendendo, mas das situações do mundo, nas quais vimos, experimentamos, aprendemos. Tais situações implicam o próprio corpo e o corpo dos outros, o espaço onde se viveu, enfim, o horizonte do mundo e dos mundos, sob o qual alguma coisa aconteceu. (2007, p.53)

No bojo do "processo memorial", fazem parte da reminiscência, portanto, diários íntimos, memórias e antimemórias, autobiografias, "em que o suporte da escrita confere materialidade aos rastros conservados, reanimados e novamente enriquecidos por depósitos inéditos" (RICOEUR, 2007, p.56). As palavras do filósofo nos remetem, assim, ao processo memorial de Jacques Chessex, o "escritor de Ropraz", para compor sua obra. Além do prefácio-paródia, no qual o narrador anuncia a veracidade dos fatos relatados, no espaço biográfico chessexiano encontramos diversas entrevistas, como a concedida ao jornal suíço "Le Messager", em 15 de junho de 2007, ou à jornalista Geneviève Bridel, publicada no livro anteriormente citado, ou ainda a autoindagação que resultou no livro póstumo L'Interrogatoire, de 2011.

$\mathrm{Na}$ entrevista ao jornal, Jacques Chessex aponta que as principais informações para a escritura de Le Vampire de Ropraz 
vieram de fontes orais da cidade de Ropraz. Na mesma entrevista, o autor revela que sabe o nome do verdadeiro culpado dos crimes de Ropraz e que possui a arma do crime. A confluência da questão espaço-memória não é em absoluto ignorada pelo escritor suíço. Em Jacques Chessex - Transcendance et transgression, ele diz:

Eu me dou conta de que a Suíça, que em muitos aspectos me contraria - sua frigidez política, sua recusa em integrar a União Europeia etc - é um formidável reservatório de imagens. A Suíça é um mundo plástico sedutor [...]. Este país manifesta uma audácia, uma inteligência plástica, poética e arquitetônica, uma inventividade, que contrastam expressivamente com sua pusilanimidade política e intelectual de hoje. (BRIDEL, 2002, p.152-153 tradução minha)

Jacques Chessex, na citada passagem, retomando a "materialidade dos rastros conservados, reanimados e novamente enriquecidos por depósitos inéditos", mencionada por Paul Ricoeur, revela sua profunda consciência pelo que pode ser compreendido como o patrimônio cultural de sua pátria, patrimônio este que inclui, ao lado de nomes ilustres e riquezas iconográficas, o posicionamento político e intelectual dos suíços. E é nesse sentido que o escritorvampiro, aquele exigido pelo narrar enquanto experiência de certa forma de viver, precisa fazer emergir o não-dito. Em Le Vampire de Ropraz, o não-dito é a identidade do necrófilo. Em Ropraz, a imagem indefectível é deslocada da verdadeira identidade do assassino para a agilidade na solução do caso - e, nesse sentido, qualquer hipótese convincente basta como verdade.

Em outro sentido, o silêncio da ironia contém uma dimensão julgadora que induz à "percepção simultânea do dito e do não dito" 
(HUTCHEON, 2000, p.66). Ou melhor, como amplia Linda Hutcheon, "o poder do não dito de desafiar o dito é a condição semântica que define a ironia" (2000, p.91). Para tanto, ou seja, para que a ironia ocupe esse espaço semântico, é preciso que ela inclua atitude e julgamento compartilhados entre o ironista e o interpretador. É nesse compartilhamento (ou em sua ausência) que a ironia produzirá seus efeitos - do prazer à raiva.

No espelho da intenção do ironista está o ponto de vista do interpretador da ironia, cuja afetividade varia do prazer à dor, da diversão à ira. Em críticas publicadas em jornais suíços na ocasião do lançamento de Le Vampire de Ropraz, a ironia estilística de Jacques Chessex é ignorada, enquanto a ênfase se situa na questão da veracidade dos fatos relatados. Em nossa visão, a falha em captar a ironia - ou a opção em ignorar o recurso - por essa plateia de críticos-leitores-interpretadores de Le Vampire de Ropraz situase justamente na permanência da neutralidade, que infere tanto o "lavo minhas mãos" quanto o "não me concerne".

Nesse sentido, a recorrência em citar o fait divers é reveladora, já que se trata, por definição, de um tipo de assunto jornalístico inclassificável, que não se inclui em nenhuma outra editoria. Assim sendo, estamos tratando de um fato jornalístico cuja própria definição sugere marginalidade e superficialidade. São eventos que, aparentemente, não têm efeito sobre o funcionamento da sociedade, apenas testemunhando sua face maldita. Essa é a compreensão do senso comum sobre a rubrica.

O escândalo e o bizarro estão relacionados ao entretenimento, à diversão, e não ao que deve ser levado a sério. Assim, ao repetirem que o livro de Jacques Chessex é "baseado em fatos reais" da ordem 
do fait divers, os críticos do jornalismo literário preservam essa característica do alheamento (neutralidade), que naturalmente induz à exclusão. Nesse caso, interpretar o romance de Jacques Chessex "ao pé da letra" é retirá-lo do jogo da ironia, exercendo, assim, a premissa de interpretador. "Afinal, a responsabilidade última de decidir se a ironia realmente acontece numa elocução ou não (e qual é o sentido irônico) é apenas do interpretador" (2000, p.74), afirma Linda Hutcheon, para quem a ironia pode ou não ser intencionada pelo ironista, ao passo que é sempre um caso de interpretação e atribuição.

A partir do exposto, podemos concluir que, para Jacques Chessex, revisitar o sombrio e o "esquecido" da sua história biográfica e patrícia é, ao mesmo tempo, transgressão e abertura. Uma reação a uma "espécie de nanismo" a que a Suíça estaria condenada, pela falta de audácia em romper as barreiras geográficas e mentais (BRIDEL, 2002, p.163). A imagem a que o escritor recorre, remontando a um cartaz visto no período da Segunda Guerra, é aquela do fantasma com o dedo sobre a boca, dizendo: "quem não sabe se calar prejudica o país". Tal imagem é relacionada por ele, mais uma vez, à oposição claro-escuro: "Eu também achava estranho o obscurecimento imposto naqueles anos. Tudo era azul e negro, não havia iluminação externa, a noite estava em todos os lugares" (BRIDEL, 2002, p.41).

Para romper a noite eterna do esquecimento imposto, aquele que seria equivalente, na classificação de Paul Ricoeur, ao esquecimento por apagamento de rastros ${ }^{13}$, Jacques Chessex põe em cena o seu duplo, o vampiro de Ropraz, cuja imortalidade representa a arte:

13 Paul Ricoeur reconhece, em A memória, a história, o esquecimento, duas grandes figuras do esquecimento: o esquecimento por apagamento de rastros (profundo) e o esquecimento de reserva (reversível). 
"Há menos de morte quando há mais de arte. [...] Isso é certo. Há uma espécie de perfusão da eternidade pela obra de arte, pelas elevações onde arde essa soberba chama que encontramos em uma pintura, uma obra, um poema, um ensaio" (BRIDEL, 2002, p.194).

Negociação entre apagamento e conservação. Essa é a leitura que Roger Bozzetto faz do vampiro moderno no artigo "Le trésor du vampire". ${ }^{14}$ Para Bozzetto, um dos "tesouros" do vampiro moderno é que ele fala de si, descortina sua biografia e segredos, compartilhando sua experiência de vida. Paralelamente, a visão de mundo do vampiro moderno evolui com o tempo, assim como sua força física. Em jogo, está a busca primordial: "Além disso, assim como os humanos, os vampiros modernos estão em busca de seu criador, à procura de suas origens, de um segredo: encontrar aquele que sabe para enfim saber (Lestat) ou, como Timmy Valentine, buscar uma plenitude perdida" (BOZZETTO, 1993, p.149, tradução minha).

Para esse vampiro moderno, a busca de suas origens orienta o herói a remontar um tempo mítico, naquela nesga que Ricoeur chama de negociação entre memória e esquecimento. Para o vampiro de Ropraz, não é exatamente um tempo imemorial que é buscado, mas outra forma de identidade, aquela que liga o mito e o homem, permitindo uma reflexão sobre nosso estatuto original. Surgindo como nossa face escondida, jamais refletida no espelho, o vampiro de Ropraz representa, portanto, uma busca autoral pelo velado, pelo encoberto, que inclui o medo traduzido em reescritura, a imortalidade traduzida em arte e a plenitude perdida traduzida em preservação de rastros. 


\section{REFERÊNCIAS}

BENJAMIN, Walter (1989). Obras escolhidas III. São Paulo: Brasiliense.

BOZZETTO, Roger (1993). "Le trésor du vampire" In: FAIVRE, Antoine (org.). Les Vampires - Colloque de Cerisy. Cahiers de I'Hermétisme. Paris: Éditions Albin Michel, p.146-154.

BRIDEL, Geneviève (2002). Jacques Chessex - Transcendance et transgression, entretiens avec Geneviève Bridel. Lausanne: La Bibliothèque des Arts.

CENDRARS, Blaise (2003). Morravagin: romance. O fim do mundo filmado pelo anjo Notre-Dame. Dorothé de Bruchard (Trad.). Carlos Augusto Calil (Coord.) São Paulo: Companhia das Letras.

CESAR, Constança Marcondes (2011). "Temporalidade e literatura". In: PAULA, Adna Candido de; SPERBER, Suzi Frankl (Org.). Teoria literária e hermenêutica ricoeuriana - Um diálogo possível. Dourados, MS: UFGD, p.165-175.

CHESSEX, Jacques (1991). Flaubert ou le désert en abîme. Paris: Grasset. (1996). La Mort d'un juste. Paris: Grasset.

(2006). Avant le matin. Paris: Grasset. (2007). Le Vampire de Ropraz. Paris: Grasset.

(2009). Un juif pour l'exemple. Paris: Éditions Grasset \& Fasqualle. (2011). L'Interrogatoire. Paris: Grasset.

ECO, Umberto (2003). "A função dos intelectuais". Revista Época, fev.03. In http://revistaepoca.globo.com/Revista/Epoca/0,,EDR55351-6075,00.html Acesso em 29.Jan.2019.

FAIVRE, Antoine (Org.) (1993). Les Vampires - Colloque de Cerisy. Cahiers de I'Hermétisme. Paris: Éditions Albin Michel.

HUTCHEON, Linda (1991). Poética do pós-modernismo: história, teoria, ficção. Ricardo Cruz (Trad.). Rio de Janeiro: Imago.

KRISTEVA, Julia (1980). Pouvoirs de l'horreur: essai sur l'abjection. Paris: Éditions du Seuil.

KUNDERA, Milan (2009). A arte do romance. Teresa Bulhões Carvalho da Fonseca (Trad.). São Paulo: Companhia das Letras. 
LECOUTEUX, Claude (2005). História dos vampiros: autópsia de um mito. Álvaro Lorencini (Trad.). São Paulo: Editora Unesp.

PAZ, Octavio (1984). Os Filhos do Barro: do romantismo à vanguarda. Olga Savary (Trad.). Rio de Janeiro: Nova Fronteira.

RICOEUR, Paul (2007). A memória, a história, o esquecimento. Alain François (Trad.). Campinas, SP: Editora da Unicamp. (2010). Tempo e narrativa - A configuração do tempo na narrativa de ficção. Vol. 2. Márcia Valéria Martinez de Aguiar (Trad.). São Paulo: Editora WMF Martins Fontes. 